\title{
Teacher pay and student performance: Evidence from Brazil
}

\author{
PRISCILLA TAVARES* \\ VLADIMIR PONCZEK*
}

\begin{abstract}
In this paper, we provide evidence of the effects of teacher's pay increases on students' learning in the context of developing countries (São Paulo state public education). We explore the variation in teachers' pay, given by the rule of additional salaries by length of service (quinquennium rule). We observed each teacher's eligibility for salary increases and explored the differences in the teachers' admission date throughout the year to calculate the exposure time of teachers treated at higher salaries. We employ a difference-indifferences strategy to control for unobserved characteristics of teachers belonging to different admission cohorts. Our results are in line with empirical literature: salary increases for incumbent teachers do not seem to affect their productivity and, therefore, are not capable of impacting student learning in basic education.
\end{abstract}

Keywords: teachers wage, teachers career, learning

JEL Codes: 128, J45

\section{Introduction and Literature Review}

There is a consensus that teacher quality is the most important input to improve student learning and reduce educational inequalities (Hanushek \& Raymond, 2005). For this reason, it is extremely important to investigate the effectiveness of public policies intended to attract and retain good professionals for educational systems and to improve the productivity of incumbent teachers.

One of these policies refers to the remuneration of teachers. From a theoretical point of view, higher salaries would attract more people to the teaching career. The greater number of professionals would have the potential to raise the average quality of teachers, since educational systems could be more selective in hiring. It could still raise the level of effort, reduce turnover and absenteeism, if the

Submitted on 11 January 2018; Reviewed on 27 September 2018

* Fundação Getulio Vargas, Escola de Economia de São Paulo (FGV/EESP). Rua Itapeva, 474, Bela Vista, São Paulo, SP, CEP 01332-000, Brasil.

apriscilla.tavares@fgv.br avladimir.ponczek@fgv.br 
salaries were higher than the sufficient level to attract the professional with the necessary minimum skills. For the educational context, the strong effects of the learning curve and the high variance in teachers' quality would justify wage-efficiency policies. Finally, higher salaries could still act as compensatory differentials, in order to attract the best teachers to the worst schools, improving the teacher-student matching.

In the empirical literature, there is evidence that higher wages induce individuals with higher academic skills to choose a teaching career (Leigh, 2012; Chevaliar, Dolton, \& McIntosh, 2007; Cassandra M. Guarino, Daley, \& Brewer, 2004; Shin \& Moon, 2006; Han \& Rossmiller, 2004; Dolton \& Makepeace, 1993; Dolton, 1990; Manski, 1987; Zibalza, 1979). Higher wages are also associated with lower turnover and higher retention of teachers in schools and in the career (Boyd, Lankford, Loeb, Rockoff, \& Wyckoff, 2007; Johnson, Berg, \& Donaldson, 2005) and to reduce the shortage of teachers in areas such as mathematics and science (Rumberger, 1987; Darling-Hammond \& Hudson, 1989; Southwick \& Gill, 1997).

However, the effects of salaries on student learning are less conclusive. The literature does not find a systematic positive relationship between wage levels and measures of proficiency or other educational outcomes, such as approval or completion (Podgursky, 2011). The absence of robust evidence of the relationship between teachers' wages and learning has led to the conclusion that salary increases may not actually be able to raise the quality of teachers (with low skills) who are already hired. Other authors argue the opposite, stating that increase in wage levels have the potential to affect teacher effort and therefore learning. However, it should be accompanied by complementary policies, such as greater autonomy for school managers, which would allow them, for example, to hire and dismiss teachers (Hanushek, 2003; Milanowski, 2008). Loeb and Page (2000), on the other hand, affirm that the literature does not adequately consider the opportunity cost of teaching and that, by including controls for non-pecuniary attributes and by remuneration in alternative occupations, there are positive effects of salaries on reduction of school dropout.

Finally, Hanushek and Rivkin (2006) point out that the literature do not provide reliable estimates of the relationship between the remuneration of inservice teachers and learning. This is mainly due to the fact that salary policies in public schools are associated with other factors that may affect proficiency, such as the characteristics of teachers related to their educational background 
and experience. In addition, most of these studies use empirical strategies that exploit differences in teacher salaries across districts or different educational systems. It can lead to misleading results, since wage increases interventions should act in other dimensions that also affect school results.

In this article, we study the effects of teachers' salaries on students' proficiency in São Paulo, Brazil, taking advantage of the existence of a rule of wage variation based on tenure (the so-called quinquennial rule). For a specific sample of teachers and, under certain hypotheses, this rule provides an exogenous variation in teachers' salaries. This article contributes to the literature with consistent estimates of the relationship between the level of regular wages and learning in the case of developing countries. The quinquennial rule ensures that every five years of service time, teachers receive a $5 \%$ increase in regular salary. Thus, we used the date of admission of teachers to evaluate their eligibility for salary increase and the time of exposure of teachers who received higher salaries, exploring the differences in the timing of hiring the teachers throughout the year. Our results are in line with International empirical literature: wage increase for incumbent teachers seems not to affect their productivity and is not able to impact student learning in basic education.

This article is organized as follows. Section 2 describes the characteristics of the salary policy of the São Paulo State. Sections 3 and 4 present data, descriptive statistics and empirical strategy. Section 5 discusses the results and section 6 concludes.

\section{Teacher Career in São Paulo}

According to data from the School Census, the São Paulo educational system is responsible for serving 2.0 million primary school students and 1.6 million high school students, by about $30 \%$ of Brazilian students. It employs almost 150,000 teachers $\left(70 \%\right.$ have employment stability) to teach in elementary school $\left(1^{\text {st }}\right.$ to $5^{\text {th }}$ years, PEB I career) and in the second cycle of primary education $\left(6^{\text {th }}\right.$ to $9^{\text {th }}$ grade) or high School (PEB II career).

Teacher remuneration is composed of basic salary and some rewards, associated with qualification and tenure. Teachers' salaries rise according to their five-level classification of the teacher evaluation. They are classified in the first level when they are hired (level I) and the change to higher levels could occur through academic or non-academic ways. Each time the teacher reaches a higher level, the salary increases by $5 \%$. 
Academic progress is achieved when the teacher qualifies for a higher education degree or completes master's or doctoral courses in the area of education. Teachers in PEB I career completing graduation pass from level I to level IV. All teachers that conclude master's and doctoral degrees, evolve to levels IV and $\mathrm{V}$, respectively.

Non-academic progress is based on education, training and professional production factors. In the education factor are considered diplomas of graduation and post-graduation in non-specific areas (not related to education), as well as participation in courses for professional development. The training factor takes into account the participation in lectures, seminars and short courses and the professional production factor considers the publication of articles in scientific journals, books, research reports and didactic material. For each of these indicators there is a distint score and the progress to a higher level requires that the teacher reach a minimum score (Tables 1 and 2).

Table 1. Score of teacher evaluation indicators.

\begin{tabular}{lcc}
\hline & Score & Maximum score \\
\hline Education & & - \\
Doctorate degree & 14 & - \\
Master & 12 & - \\
Specialization (360 hours minimum) & 11 & - \\
Development (at least 180 hours) & 9 & - \\
Bachelor's Degree & $8-10$ & - \\
University Extension & $3-7$ & \\
\hline
\end{tabular}

Training: Participation in conferences, seminars, courses

30 to 59 hours 3

60 to 89 hours $\quad 5$

90 to 179 hours $\quad 7$

180 hours or more $\quad 9$

\begin{tabular}{lcc}
\hline Professional Production & & \\
Book & $5-12$ & - \\
Academic paper & 3 & 9 \\
Educational or video software & 5 & 15 \\
Research report in the area of education & 5 & 15
\end{tabular}

Source: SEE/SP.

The weight of each indicators varies according to the teacher's position in the evaluation levels: at lower levels, the education and training factors are more important and at the higher levels, the professional production are more valuable. 
Table 2. Parameters of teacher evaluation.

\begin{tabular}{lcccc}
\hline Level & $\begin{array}{c}\text { Minimum } \\
\text { Score }\end{array}$ & $\begin{array}{c}\text { Education } \\
\text { Weight }\end{array}$ & $\begin{array}{c}\text { Training } \\
\text { Weight }\end{array}$ & $\begin{array}{c}\text { Professional } \\
\text { production weight }\end{array}$ \\
\hline I to II & 35 points & 4 & 4 & 2 \\
II to III & 40 points & 4 & 4 & 2 \\
III to IV & 50 points & 3 & 3 & 4 \\
IV to V & 60 points & 3 & 3 & 4 \\
\hline
\end{tabular}

Source: SEE/SP.

The salary progression also varies with the time of service of the teacher in the state education system. All teachers that have job stability are eligible to earn an additional remuneration called quinquênio. Every time the teacher completes five years in the job, her salary increase by $5 \%$ immediately. The length of service counts starts on the date of hiring and this count is practically continuous. This is because almost no absence is considered to reduce the length of service, as maternity leave, leave for the death of relatives, administrative proceedings, other public activities, participation in union activities, justified absences or absences due to medical reasons, licenses for work-related accidents or illnesses, sick leave for infectious diseases. Only long-term leaves for health treatment can reduce the length of service count. ${ }^{1}$

Figure 1 shows how teachers' salaries vary with their length of service. ${ }^{2}$ This figure reveals many important aspects of the salary progression in São Paulo educational system. First, teachers' salaries are approximately $5 \%$ higher when they complete five-year in the job. In addition, qualification, training and production also impact teacher compensation. In each service time bracket, five well-defined lines representing teachers' salaries at each level of teacher evaluation are observed. However, relatively few teachers are able to evolve beyond the second level. Among teachers in the same service time bracket, the participation of teachers in the level I is always higher.

\footnotetext{
1 Teachers who ask to health leave are those who need to move away for long periods for health treatment. This is because short-term absences are considered health absences. Moreover, when the disease is contagious or when the medical certificate states that the health problem is related to the teacher's work (such as voice problems, back pain and stress), the absence does not affect the effective time exercise. Nevertheless, according to the SEE, there are several cases of teachers who have applied for health leave and have had time off from the actual exercise, but have won legal cases against the State so that the length of service is not interrupted. The severity of the illness that motivated the removal should not hinder wages.

${ }^{2}$ Considering PEB II teachers, with 30 hours weekly contract. The same pattern is observed for teachers with other work contracts.
} 


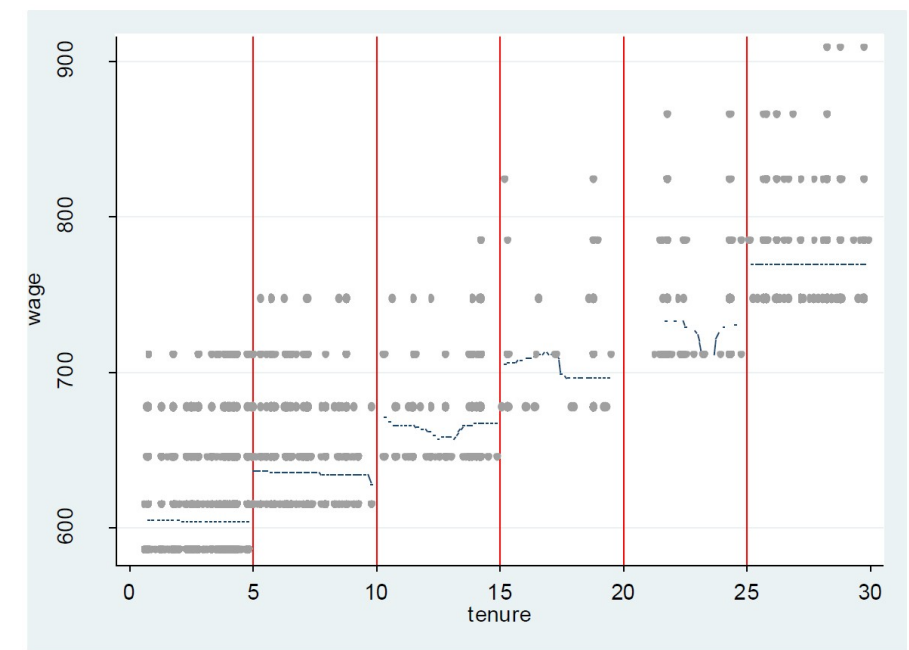

Source: DRHU/SEE.

Figure 1. Evolution of basic salary according to tenure.

Finally, and more important for the purposes of this article, the distribution of teachers among evaluation levels is relatively homogeneous over the length of service. This shows that the teacher's chance of career progression by academic or non-academic ways does not seem to change when he is about to complete a five-year career cycle.

\section{Data and Descriptive Statistics}

We use three sources of information: SARESP and the Census of Basic Education and administrative data of the Department of Human Resources of the São Paulo State Department of Education (DRHU/SEE) for the school year of 2007.

The SARESP database (Sistema de Avaliação de Rendimento do Estado de São Paulo) contain language and math proficiency of all elementary school $\left(5^{\text {th }}\right.$ and $9^{\text {th }}$ grades) and high school students $\left(3^{\text {rd }}\right.$ year) as well as socio-demographic characteristics and students' family background data. The DRHU/SEE database has information from teachers who have job stability and has working for the entire year in 2007 (almost 70,000 observations). It includes personal and demographic characteristics (gender, race, age, date of birth, ID), the job category (PEB I or PEB II), work contract in terms of the weekly working day $(12,20,30$ or 40 hours), the classification in the teacher evaluation (level I up to level $\mathrm{V}$ ), the basic salary (in $\mathrm{R} \$$ ), the date of admission in SEE (day, month and 
year) and the list of schools in which each teacher is allocated each year. This database does not link the teacher to the class. The Census of Basic Education, in turn, identifies in which schools and classes the teacher is allocated in each period and which are the disciplines that she teaches in each of them, in addition to include demographic and educational data also.

In order to relate the educational performance information of each class to the demographic and work characteristics of their teachers, we match the three databases. The identification of the classes in SARESP and the Census is immediate, since the code of the classes in the two databases is identical (INEP code). The matching of DRHU and Census databases is not trivial. This is because they do not have a common teacher identification. For this reason, we used a pairing procedure of the two bases, using teachers' date of birth, gender and school ID.

In the first stage, we find unique observations of teachers who teach at the same school, are of the same sex and were born the same year. Thus, if at school A, there is only one woman born in 1960 in the Census and DRHU databases, we conclude that she is the same teacher. If there are duplicate observations in one of the databases (for example, two women born in 1960 at the same school), the second stage is included, which includes the information of the month of birth. If duplicity persists, birth-date information is included in the third step of pairing. After pairing the DRHU and Census databases, we were able to obtain the code of the classes for which the teacher attend, so that it is possible to link to each teacher the average proficiency of his students.

Excluding the professors who hold a management position (pedagogical coordinators, vice-principals and principals), the DRHU/SEE database includes information on 55,194 teachers who taught in the state of São Paulo in 2007 and who have information on the schools in which she teaches. The SARESP microdata contains information of 32,350 and 32,416 classes, evaluated in 2007, respectively. After pairing with the Census database, the resulting sample corresponds to $65 \%$ of PEB I teachers and $82 \%$ of PEB II teachers; $77 \%$ of the $5^{\text {th }}$ grade classes, 98 of the $9^{\text {th }}$ grade classes and $99 \%$ of the high school classes. ${ }^{3}$

Table 3 presents the descriptive statistics of the sample and compares the groups of treated and untreated teachers. The majority of the teachers are female $(74 \%)$, have completed higher education (99\%), teach in the second cycle

\footnotetext{
3 There are no significant differences in teacher characteristics and proficiency averages between the non-paired and paired samples. Results can be requested for authors.
} 
Table 3. Teachers characteristics (differences by treatment status).

\begin{tabular}{lcccc}
\hline & Full sample & Control & Treatment & Difference \\
\hline Demographic characteristics & & & & \\
Woman & 0.74 & 0.72 & 0.76 & $0.04^{* * *}$ \\
& $(0.002)$ & $(0.003)$ & $(0.003)$ & $(0.004)$ \\
Age & 40.69 & 38.07 & 44.24 & $6.17^{* * *}$ \\
& $(0.039)$ & $(0.053)$ & $(0.047)$ & $(0.073)$ \\
Higher education & 0.99 & 0.99 & 0.99 & $0.00 * * *$ \\
& $(0.000)$ & $(0.001)$ & $(0.001)$ & $(0.001)$ \\
Labor characteristics & & & & \\
PEB II & 0.92 & 0.91 & 0.93 & $0.02^{* * *}$ \\
& $(0.001)$ & $(0.002)$ & $(0.002)$ & $(0.002)$ \\
Experience & 5.91 & 2.69 & 10.28 & $7.59 * * *$ \\
& $(0.025)$ & $(0.020)$ & $(0.035)$ & $(0.037)$ \\
40-hours contract & 0.11 & 0.10 & 0.12 & $0.02 * * *$ \\
& $(0.001)$ & $(0.002)$ & $(0.002)$ & $(0.002)$ \\
Base salary & $2,050.33$ & $1,945.12$ & $2,191.56$ & $246.44^{* * *}$ \\
& $(3,128)$ & $(3,897)$ & $(4,966)$ & $(6,225)$ \\
\hline Observations & 48,865 & 28,004 & 20,861 & \\
\hline
\end{tabular}

Notes: Standard error in parentheses. ${ }^{* * *} p<0.01 ; * * p<0.05 ; * p<0.10$.

Source: DRHU/SEE.

of elementary education or in high school (92\%) and do not work full-time (only $11 \%$ have a 40 -hour weekly contract). The average age and experience in the São Paulo educational system are 41 and 6 years, respectively, and the base salary is $\mathrm{R} \$ 2.050$ on average. There are statistically significant differences between the sample of treated and untreated teachers. Among the teachers in the treatment group, the proportion of women and the mean age is higher in relation to the control group. Although the difference in the educational background of teachers between the treatment and control groups is statistically significant, it is very close to zero. Among the teachers treated, there is greater representation of those who teach in the second cycle of elementary and high school (93\%), as well as those who have a 40 -hour contract (12\%). Particularly, by the definition of treatment, the average length of service is higher among the teachers treated (almost 8 years), as well as the basic salary (about $\mathrm{R} \$ 250$ ). Approximately $75 \%$ of the treated teachers are in the first five-year period, that is, they have completed five years of experience in 2007. 


\section{Identification and Empirical Strategy}

The challenge of identifying the causal effect of teachers' salaries on learning is that, in general, the factors that affect the salary progression can be correlated with teachers' quality and, therefore, with the performance of students (qualification). In this paper, we use an exogenous source of wage variation, given by the quinquennial rule. We describe below our empirical strategies and explain the effects they are able of identifying.

How can the quality of the teacher vary according to his salary? Let us imagine that with a higher salary, the teacher is able to reallocate her time and, in this way, to exert more effort in the preparation of material, in the planning of didactic activities and in the improvement of her teaching strategies. If this additional teacher effort has a cumulative impact on student learning, the time elapsed since the teacher received a salary increase has a first-order effect on proficiency. The great problem of identification in this case is that this effect is confused with the effect of the gain of experience of the teacher, since the increase of salary by the rule of quinquennial occurs in her employment birthday.

We assume that the learning technology follows the function described as follow. The key hypothesis here is that the effects of salary and teacher experience on proficiency are independent:

$$
Y_{p}=\int_{t=\bar{t}}^{P} g\left(w_{t}\right) \mathrm{d} t+f\left(\operatorname{Exp}_{p}\right)+\varepsilon_{p}
$$

where $Y_{p}$ is the proficiency of the students of teacher $p ; w_{t}$ is the teacher's salary which can vary according to $t ; \bar{t}$ is the beginning of the school year and $P$ is the SARESP exam day; $\operatorname{Exp}_{p}$ is the teacher's experience in years; and $\varepsilon_{p}$ the idiosyncratic teachers' attributes. In this case, the impact of the teacher's salary increase on learning would depend on how long the teacher is receiving higher salaries until the date of proficiency measurement (SARESP examination). If we consider $g(\cdot)$ and $f(\cdot)$ as linear functions and that the salary increase occurs only once in the year, we can rewrite the learning technology function as

$$
Y_{p}=\alpha+\beta\left(P-Q_{p}\right)+\gamma P+\varepsilon_{p}
$$

where $Q_{p}$ is the date of the teacher's salary increase.

To capture this effect of teacher salary increase on grades, we employ an intra-cohort analysis from a difference-in-differences strategy, which explores 
the variation in the month of admission over the year in which the teacher completes an employment anniversary. Admission to the São Paulo educational system requires that the teacher be approved in a competitive exam. Upon registered in the exam, the candidate chooses the school district (municipality or neighborhood) where she wishes to teach and this choice cannot be changed after the test and not even three years after joining the educational system. The order of hiring follows the classification of the teacher at the level of the district and the availability of vacant job in the chosen location. In general, hiring selection processes occur at the end of the year. Most teachers are hired until the beginning of the school year in the following year. However, since the exams are valid for two years, with vacancies available, those approved may be called upon to take up their position at any time of the year. Thus, the month in which the teacher was hired correlates with her rank in the entry exam of the admission cohort to which she belongs and possibly with unobservable characteristics related to teacher quality. Thus, we explored this variation in the admission month to control for possible heterogeneities among the different admission cohorts, estimating model (1):

$$
\begin{aligned}
y_{i p s}=\beta_{0}+\beta_{1} T_{p}+\beta_{2} T D_{p}+\beta_{3} T_{p} * T D_{p}+\sigma T S_{p}+ & \tau T S_{p}^{2}+\gamma X_{p} \\
& +\alpha X_{i}+\delta_{s}+\vartheta_{i p s},
\end{aligned}
$$

in which

$$
\begin{aligned}
y_{\text {ips }}= & \text { grades of class } i, \text { of teacher } p \text {, at school } s . \\
T_{p}= & \text { dummy that indicates if the teacher } p \text { completes a quin- } \\
& \text { quennium in } 2007 . \\
T S_{p}= & \text { years in the job of teacher } p \text { (continuous variable). } \\
X_{p}= & \text { vector of teachers characteristics of teacher } p \text { (gender, color, } \\
& \text { age, qualification, dummies for } 20,30 \text { and } 40 \text {-hour con- } \\
& \text { tracts). } \\
X_{i}= & \text { vector of characteristics of class } i \text { (proportion of boys, pro- } \\
& \text { portion of whites, average age, parental education, income } \\
& \text { indicators). } \\
\delta_{s}= & \text { school fixed effects. } \\
\vartheta_{i p s}= & \text { unobservable variables of class } i, \text { of teacher } p, \text { in school } s .
\end{aligned}
$$




$$
\begin{aligned}
T D_{p}= & \text { time elapsed since the last job anniversary until the month } \\
& \text { of the SARESP tests. } \\
T D_{p}= & T S_{p}-x, \text { em que } x=0,1, \ldots, 45 \text { e } x \leq T S_{p}<x+1 .
\end{aligned}
$$

The variable $T S_{p}$ is a continuous variable that represents the service time (in years) of the teacher $p$ until the month of the SARESP exams, and is calculated as follows, for $t=2007,2008$ :

$$
T S_{p}=t-\text { admission year }{ }_{p}+\left(1-\frac{\text { admission month }}{p}\right) .
$$

If the teacher was admitted in January of 2007, in November of this same year his time of service will be equal to 0.9167 . The teacher admitted in January 2000 will have a service time equal to 7.9167. With the information of the year of admission, we are also able to observe at what point the teacher completes a quinquennium (anniversary of five years of employment) and therefore, which are the teachers treated by the policy of salary increase by time of service in each period.

For a given admission cohort, the $T D_{p}$ measures, on the date of the SARESP proficiency exams, how long the teacher completed an employment anniversary. For example, in November 2007 (month in which the tests took place), the teacher who was hired in January 2000 will have 7.9167 years of service time and, therefore, $T D=0.9167$. The teacher hired in May 2000 will have 7.4167 years of service time and, therefore, $T D=0.9167$. Figure 2 shows the distribution of all teachers in the sample, according to the month of admission in the state network. The red line refers to the set of teachers who completed a five-year cycle of service time in 2007 (treated). The blue line includes the other (untreated) teachers. It is noteworthy that, although most of the teachers were hired between January and March, there are a significant number of teachers hired over the following months.

Among teachers who do not complete quinquennials in the year in which we observe student proficiency (2007), this variable is related to the teacher's ranking in the entry exam and measures their experience gain throughout the year. Among treated teachers, who complete quinquenniums this year, this variable also measures how long the teacher has been receiving higher salaries. This is because the salary increase is granted in the month in which the teacher completes a five-year (or multiple) employment cycle. When comparing the two groups of teachers, this strategy equals a difference-in-difference one. The 


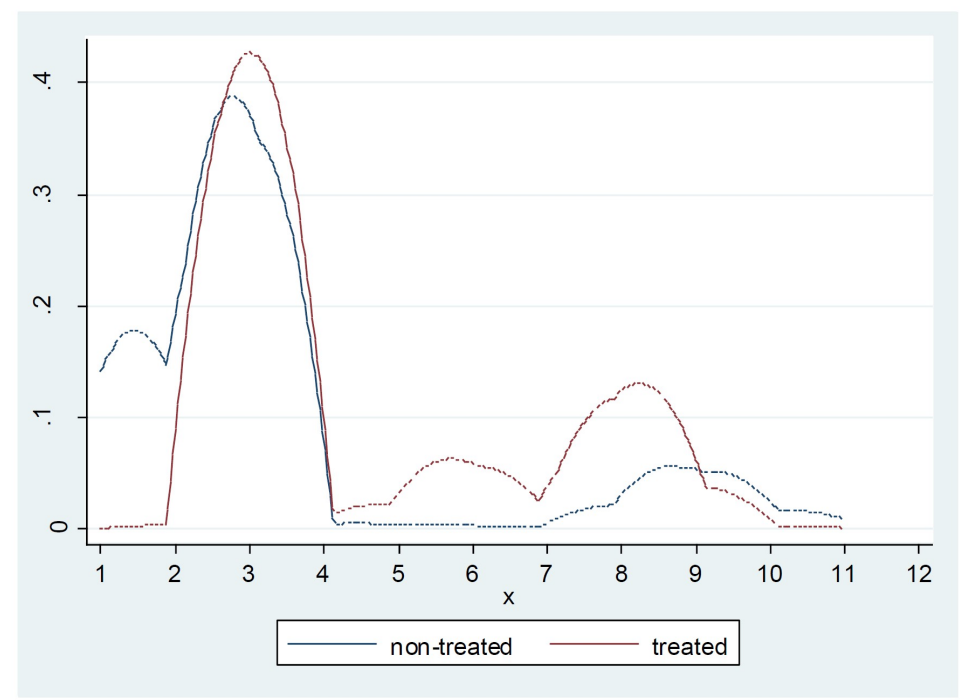

Source: DRHU/SEE.

Figure 2. Distribution of teachers, according to the month of admission.

parameter $\beta_{2}$ captures the heterogeneity between teachers admitted in different months of the year, that is, it controls the teacher's differences in quality. But the parameter $\beta_{3}$ identifies the effect of salary increase on learning, since it captures differences between teachers with and without quinquennium, between teachers with similar positions in the different entry exams (measured by the month of admission). For this parameter capture the causal impact of the salary increase on proficiency, the identification hypothesis is that the difference in the quality of teachers hired in different months is homogeneous between the different admission cohorts. However, it is precisely the assumption that teachers who occupy similar positions in the ranking of exams and belong to different admission cohorts are equal in unobservable characteristics that influence their quality. This is the traditional hypothesis of difference-in-difference strategies that imposes constraints on the trajectory between groups, but not on the level difference.

At this point, it is important to evaluate what effects our econometric exercises are able of identifying. Since the quinquennial bonus is known and therefore anticipated by the teacher, our estimates refer to a kind of income effect. We can assume that teachers with lower wages decide to engage in other paid activities, for example, classes in municipal and private educational systems 
or even other professional activities. The time spent in these activities can be detrimental to their classroom performance and adversely affect the learning of their students, as the teacher should be less willing to prepare the lesson, engage in school planning activities, participate in meetings etc. Thus, under the hypothesis that the teacher faces credit restrictions, the quinquennial additional could promote a reallocation of the teacher's time, increasing her dedication to the classes. Thus, if wages impact student learning, we should expect that students whose teachers receive the quinquennial bonus have higher average scores than students whose teachers have not yet received this bonus. Likewise, students whose teachers have been paid higher salaries for a longer period of time should present higher average grades than those whose teachers received salary increases less recently. That is, we should expect a positive correlation between the average performance of the students and the variable that indicates the treatment by the quinquennium, as well as the time elapsed since the receipt of the additional five-year period among the teachers who completed a five-year job cycle in a given school year. For the context of the state of São Paulo this mechanism seems plausible, since teachers who engage in other paid activities have lower average wages than teachers working only in this educational system (Figure 5).

With this argument, the specification used in model (1) assumes that the salary effect on student performance occurs cumulatively and linearly. However, it is possible to argue about the existence of other mechanisms through which higher wages would impact performance. Assume that the salary increase instantly promote a behavioral effect that affects the morale of students and therefore their performance. ${ }^{4}$ In this case, the net average impact of the cumulative effect of time and the instantaneous effect of the wage increase on the notes could be captured by the specification described by model (2):

$$
y_{i p s}=\beta_{0}+\sum_{c=1}^{4} \beta_{c} T_{c p}+\sigma T S_{p}+\tau T S_{p}^{2}+\gamma X_{p}+\alpha X_{i}+\delta_{s}+\vartheta_{i p s}
$$

in which

$$
\begin{aligned}
y_{i p s}= & \text { grades from class } i, \text { teacher } p, \text { at school } s . \\
T_{1}= & \text { dummy that indicates if the teacher has } 5 \text { to } 9 \text { years of } \\
& \text { service time. }
\end{aligned}
$$

\footnotetext{
${ }^{4}$ We thank an anonymous reviewer for pointing out this interpretation.
} 


$$
\begin{aligned}
T_{2}= & \begin{array}{l}
\text { dummy that indicates if the teacher has } 10 \text { to } 14 \text { years of } \\
\text { service time. }
\end{array} \\
T_{3}= & \begin{array}{l}
\text { dummy that indicates if the teacher has } 15 \text { to } 19 \text { years of } \\
\text { service. }
\end{array} \\
T_{4}= & \begin{array}{l}
\text { dummy that indicates whether the teacher has } 20 \text { to } 24 \\
\\
\text { years of service. }
\end{array} \\
T S_{p}= & \text { years of service of teacher } p \text { (continuous variable). } \\
X_{p}= & \text { vector of teacher characteristics } p \text { (gender, color, age, school- } \\
& \text { ing, dummies for } 20,30 \text { and } 40 \text {-hour work contracts). } \\
X_{i}= & \text { vector of characteristics of class } i \text { (proportion of boys, pro- } \\
& \text { portion of whites, average age, parental education, income } \\
& \text { indicators). } \\
\delta_{s}= & \text { fixed effect of the school. }
\end{aligned}
$$

The treatment dummies $\left(T_{1}-T_{4}\right)$ indicate in which service time range the teacher is, and therefore, identifies in which salary range the teacher fits. The coefficients associated with these variables capture the effect of higher wages on the grades, in addition to the effect of teacher's experience under two assumptions. The first hypothesis is that the effect of experience on teacher quality is continuous with the length of service and that this effect is properly controlled by polynomial functions of experience. ${ }^{5}$ In this way, each treatment dummy would capture only the salary differences between teachers with and without quinquennia and not their differences of experience in the classroom. The second hypothesis requires that, conditional on the experience and other characteristics of the teachers, there is no heterogeneity in the quality of the teacher between different cohorts of teachers. In other words, if there are differences in the quality of the teacher among teachers who have entered the educational system at different years, they are controlled by the attributes of the teachers included as controls. This model is estimated from the 2007 SARESP data. With this, we expect to capture only the effect of the wage increase.

The models (1) and (2) were estimated using language and math SARESP grades, for $5^{\text {th }}$ and $9^{\text {th }}$ years elementary students and $3^{\text {rd }}$ year high school

\footnotetext{
${ }^{5}$ We have estimated models that consider second, third and fourth degree polynomials of the experience. The conclusions about the coefficients of interest are robust to the different specifications. Only the results of the regressions that consider the quadratic function are reported. Other results may be requested from the authors.
} 
students. The regressions for language and math were estimated considering three distinct samples of teachers: a) all matched teachers; b) area specific teachers (respectively, language/humanities and math/sciences); c) specific teachers of the subjects (language and math respectively). The effects of salaries on the average grades were estimated, as well as on the 10, 25, 75 and 90 percentiles of the grade distribution.

\section{Results}

Tables 4 to 6 present the results of the models (1) and (2), respectively, for the $5^{\text {th }}$ and $9^{\text {th }}$ years of elementary education and for the $3^{\text {rd }}$ year of high school. In order to evaluate the impact of the quinquennium for different subgroups of students, we estimate the effects along the distribution of students' grades. These impacts along the distribution can still be seen in Figures 3 to 5 . All these results refer to the estimates that consider the sample of teachers specific to each discipline, that is, in the regressions for math and language, we consider only the teachers who teach each discipline, respectively. This choice is justified by the fact that the results estimated from the three teacher samples (all teachers, area teachers and discipline teachers) are qualitatively similar. We chose to report these results by assuming that if regular wages affect learning, these effects should be greater among the specific teachers in each subject. The coefficients were standardized and therefore measure the effects in terms of standard deviations of the grades.

In Table 4 , we can note that the $5 \%$ increase in regular salaries shows a positive correlation with the average language grade in the $5^{\text {th }}$ year of elementary
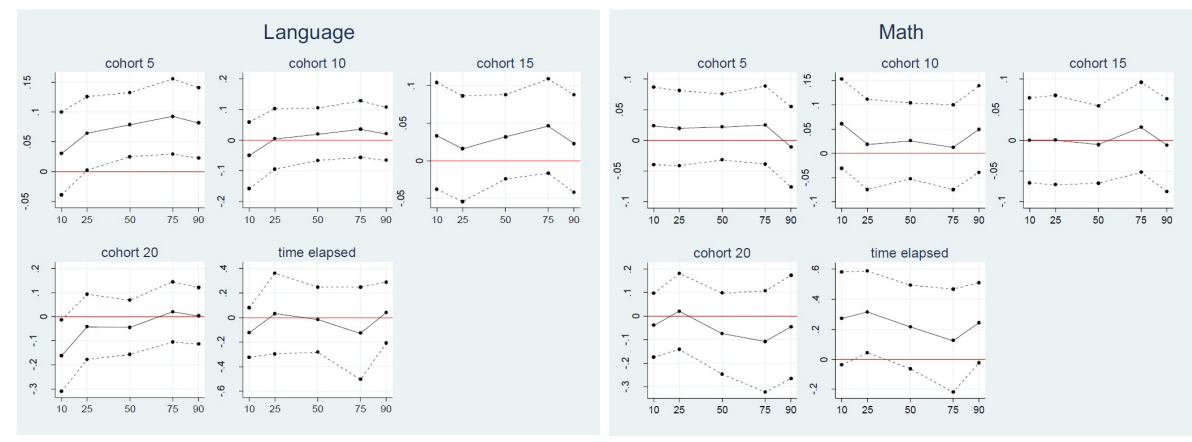

Source: SARESP, DRHU-SEE, School Census.

Figure 3. Effect of wages on proficiency $\left(5^{\text {th }}\right.$ year of elementary school). 
Table 4. Effects of wages on proficiency (Elementary school, $5^{\text {th }}$ year).

\begin{tabular}{cccccc}
\hline & $\mathbf{p 1 0}$ & $\mathbf{p 2 5}$ & average & $\mathbf{p 7 5}$ & $\mathbf{p 9 0}$ \\
\hline Intracohorts analysis $^{\mathfrak{a}}$ & & & & & \\
Language & & & & & \\
T $*$ time & -0.121 & 0.034 & -0.016 & -0.127 & 0.043 \\
& $(0.104)$ & $(0.167)$ & $(0.136)$ & $(0.192)$ & $(0.126)$ \\
$\mathrm{N}$ & 6,268 & 6,268 & 6,268 & 6,268 & 6,268 \\
& & & & & \\
Math & & & & & \\
$\mathrm{T} *$ time & $0.271^{*}$ & $0.315 * *$ & 0.216 & 0.124 & $0.243 *$ \\
$\mathrm{~N}$ & $(0.158)$ & $(0.139)$ & $(0.142)$ & $(0.174)$ & $(0.136)$ \\
& 6,439 & 6,439 & 6,439 & 6,439 & 6,439 \\
\hline
\end{tabular}

First differences ${ }^{\mathfrak{b}}$

\begin{tabular}{cccccc} 
Language & & & & \\
T5 & 0.030 & $0.064^{* *}$ & $0.079 * *$ & $0.093^{* * *}$ & $0.082^{* * *}$ \\
& $(0.035)$ & $(0.031)$ & $(0.027)$ & $(0.032)$ & $(0.030)$ \\
T10 & -0.050 & 0.005 & 0.019 & 0.036 & 0.021 \\
& $(0.055)$ & $(0.050)$ & $(0.044)$ & $(0.047)$ & $(0.044)$ \\
T15 & 0.033 & 0.016 & 0.032 & 0.046 & 0.023 \\
& $(0.036)$ & $(0.036)$ & $(0.029)$ & $(0.032)$ & $(0.033)$ \\
T20 & $-0.161^{* *}$ & -0.042 & -0.044 & 0.021 & 0.004 \\
& $(0.076)$ & $(0.069)$ & $(0.057)$ & $(0.064)$ & $(0.060)$ \\
$\mathrm{N}$ & 6,268 & 6,268 & 6,268 & 6,268 & 6,268 \\
& & & & & \\
Math & & & & & \\
$\mathrm{T} 5$ & 0.024 & 0.020 & 0.022 & 0.025 & -0.01 \\
& $(0.032)$ & $(0.031)$ & $(0.027)$ & $(0.032)$ & $(0.033)$ \\
$\mathrm{T} 10$ & 0.062 & 0.019 & 0.026 & 0.013 & 0.050 \\
& $(0.047)$ & $(0.047)$ & $(0.040)$ & $(0.045)$ & $(0.045)$ \\
$\mathrm{T} 15$ & 0.000 & 0.001 & -0.007 & 0.021 & -0.008 \\
& $(0.035)$ & $(0.037)$ & $(0.032)$ & $(0.037)$ & $(0.039)$ \\
$\mathrm{T} 20$ & -0.039 & 0.020 & -0.074 & -0.108 & -0.046 \\
& $(0.069)$ & $(0.082)$ & $(0.088)$ & $(0.109)$ & $(0.112)$ \\
$\mathrm{N}$ & 6,439 & 6,439 & 6,439 & 6,439 & 6,439 \\
\hline
\end{tabular}

Notes: Standard error in parentheses. ${ }^{a}$ Coefficient of the interaction between the treatment dummy and the time elapsed since the last job birthday. ${ }^{b}$ Coefficient of treatment dummy for different cohorts. ${ }^{* * *} p<0.01 ;{ }^{* *} p<0.05 ;{ }^{*} p<0.10$. Source: SARESP, Census of Basic Education and DRHU/SEE. 
Table 5. Effects of wages on proficiency (Elementary school, $9^{\text {th }}$ year).

\begin{tabular}{cccccc}
\hline & $\mathbf{p 1 0}$ & $\mathbf{p 2 5}$ & average & $\mathbf{p 7 5}$ & $\mathbf{p 9 0}$ \\
\hline Intracohorts analysis $^{\mathfrak{a}}$ & & & & & \\
& & & & & \\
Language & & & & & \\
$\mathrm{T} *$ time & $0.346^{*}$ & 0.182 & 0.042 & -0.276 & -0.067 \\
$\mathrm{~N}$ & $(0.189)$ & $(0.160)$ & $(0.240)$ & $(0.316)$ & $(0.223)$ \\
& 17,103 & 17,103 & 17,103 & 17,103 & 17,103 \\
Math & & & & & \\
$\mathrm{T} *$ time & & & & & \\
$\mathrm{N}$ & -0.133 & 0.232 & 0.116 & 0.102 & -0.220 \\
$\mathrm{~N}$ & $(0.110)$ & $(0.146)$ & $(0.117)$ & $(0.186)$ & $(0.144)$ \\
& 6,706 & 6,706 & 6,706 & 6,706 & 6,706 \\
\hline
\end{tabular}

First differences ${ }^{\mathfrak{b}}$

\begin{tabular}{cccccc} 
Language & & & & \\
T5 & 0.043 & 0.048 & 0.017 & 0.065 & -0.055 \\
& $(0.076)$ & $(0.065)$ & $(0.046)$ & $(0.069)$ & $(0.069)$ \\
T10 & 0.000 & 0.000 & 0.002 & 0.058 & -0.132 \\
& $(0.121)$ & $(0.105)$ & $(0.072)$ & $(0.108)$ & $(0.110)$ \\
T15 & 0.231 & $0.353^{*}$ & 0.043 & -0.051 & $-0.327 * *$ \\
& $(0.152)$ & $(0.181)$ & $(0.077)$ & $(0.122)$ & $(0.121)$ \\
T20 & 0.077 & -0.066 & -0.052 & -0.041 & -0.118 \\
& $(0.142)$ & $(0.122)$ & $(0.094)$ & $(0.147)$ & $(0.123)$ \\
N & 4,527 & 4,527 & 4,527 & 4,527 & 4,527 \\
& & & & & \\
Math & & & & & \\
T5 & 0.047 & $0.082 *$ & $0.083 *$ & 0.071 & 0.095 \\
& $(0.047)$ & $(0.047)$ & $(0.043)$ & $(0.089)$ & $(0.100)$ \\
T10 & 0.042 & 0.045 & 0.050 & 0.002 & -0.223 \\
& $(0.212)$ & $(0.173)$ & $(0.162)$ & $(0.230)$ & $(0.311)$ \\
T15 & 0.008 & 0.026 & 0.071 & 0.151 & 0.182 \\
& $(0.081)$ & $(0.108)$ & $(0.093)$ & $(0.159)$ & $(0.207)$ \\
T20 & 0.094 & 0.145 & $0.191 * *$ & $0.240 *$ & 0.189 \\
& $(0.083)$ & $(0.090)$ & $(0.083)$ & $(0.143)$ & $(0.170)$ \\
N & 3,588 & 3,588 & 3,588 & 3,588 & 3,588 \\
\hline
\end{tabular}

Notes: Standard error in parentheses. ${ }^{a}$ Coefficient of the interaction between the treatment dummy and the time elapsed since the last job birthday. ${ }^{b}$ Coefficient of treatment dummy for different cohorts. ${ }^{* * *} p<0.01 ;{ }^{* *} p<0.05 ;{ }^{*} p<0.10$. Source: SARESP, Census of Basic Education and DRHU/SEE. 
Table 6. Effects of wages on proficiency (High school, $3^{\text {rd }}$ year).

\begin{tabular}{cccccc}
\hline & $\mathbf{p 1 0}$ & $\mathbf{p 2 5}$ & average & $\mathbf{p 7 5}$ & $\mathbf{p 9 0}$ \\
\hline Intracohorts analysis $^{\mathfrak{a}}$ & & & & & \\
& & & & & \\
Language & & & & & \\
$\mathrm{T} *$ time & 2.205 & 0.159 & 0.435 & -0.108 & $-5.042^{* *}$ \\
& $(2.942)$ & $(5.129)$ & $(2.224)$ & $(1.176)$ & $(2.256)$ \\
$\mathrm{N}$ & 3,702 & 3,702 & 3,702 & 3,702 & 3,702 \\
& & & & & \\
Math & & & & & \\
$\mathrm{T} *$ time & $0.528 *$ & 0.436 & $0.783^{* * *}$ & $0.977^{* * *}$ & $1.135^{* *}$ \\
& $(0.320)$ & $(0.321)$ & $(0.268)$ & $(0.348)$ & $(0.477)$ \\
$\mathrm{N}$ & 3,682 & 3,682 & 3,682 & 3,682 & 3,682 \\
\hline
\end{tabular}

First differences ${ }^{\mathfrak{b}}$

\begin{tabular}{cccccc} 
Language & & & & \\
T5 & -0.012 & -0.001 & 0.034 & 0.034 & $0.122^{*}$ \\
& $(0.053)$ & $(0.054)$ & $(0.045)$ & $(0.068)$ & $(0.069)$ \\
T10 & 0.019 & -0.082 & 0.031 & 0.105 & 0.157 \\
& $(0.084)$ & $(0.101)$ & $(0.078)$ & $(0.105)$ & $(0.132)$ \\
T15 & 0.179 & 0.097 & $0.192^{* *}$ & 0.207 & $0.323 * *$ \\
& $(0.112)$ & $(0.106)$ & $(0.091)$ & $(0.131)$ & $(0.131)$ \\
T20 & -0.059 & 0.003 & 0.029 & 0.047 & 0.137 \\
& $(0.067)$ & $(0.075)$ & $(0.066)$ & $(0.097)$ & $(0.118)$ \\
N & 3,702 & 3,702 & 3,702 & 3,702 & 3,702 \\
& & & & & \\
Math & & & & & \\
T5 & 0.038 & 0.048 & -0.010 & -0.045 & -0.158 \\
& $(0.064)$ & $(0.070)$ & $(0.081)$ & $(0.107)$ & $(0.173)$ \\
T10 & 0.057 & 0.091 & -0.020 & -0.029 & -0.347 \\
& $(0.142)$ & $(0.162)$ & $(0.157)$ & $(0.198)$ & $(0.298)$ \\
T15 & 0.188 & 0.243 & 0.031 & -0.143 & -0.371 \\
& $(0.153)$ & $(0.168)$ & $(0.141)$ & $(0.185)$ & $(0.264)$ \\
T20 & 0.013 & 0.075 & -0.034 & -0.019 & -0.287 \\
& $(0.082)$ & $(0.090)$ & $(0.098)$ & $(0.147)$ & $(0.218)$ \\
N & 3,682 & 3,682 & 3,682 & 3,682 & 3,682 \\
\hline
\end{tabular}

Notes: Standard error in parentheses. ${ }^{a}$ Coefficient of the interaction between the treatment dummy and the time elapsed since the last job birthday. ${ }^{b}$ Coefficient of treatment dummy for different cohorts. ${ }^{* * *} p<0.01 ;{ }^{* *} p<0.05 ;{ }^{*} p<0.10$. Source: SARESP, Census of Basic Education and DRHU/SEE. 

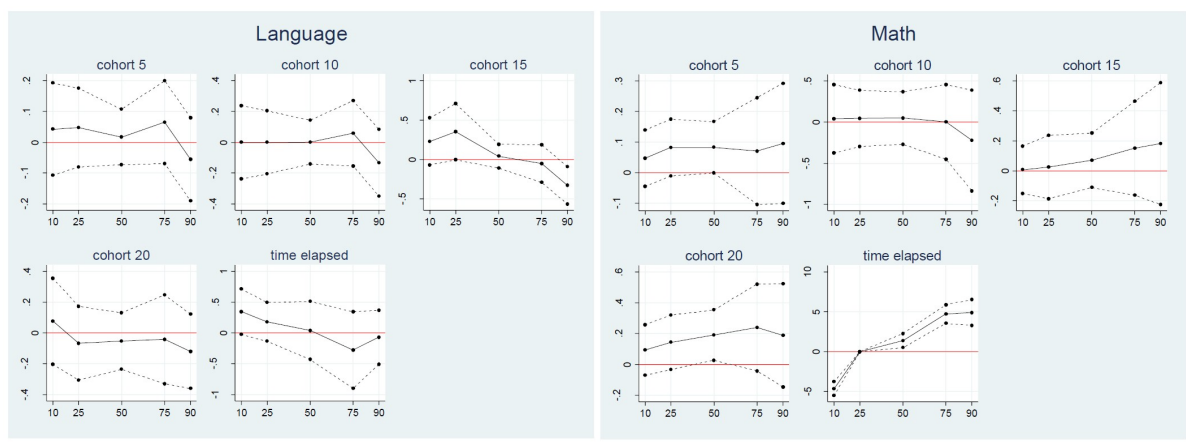

Source: SARESP, DRHU-SEE, School Census.

Figure 4. Effect of wages on proficiency ( $9^{\text {th }}$ year of elementary school).
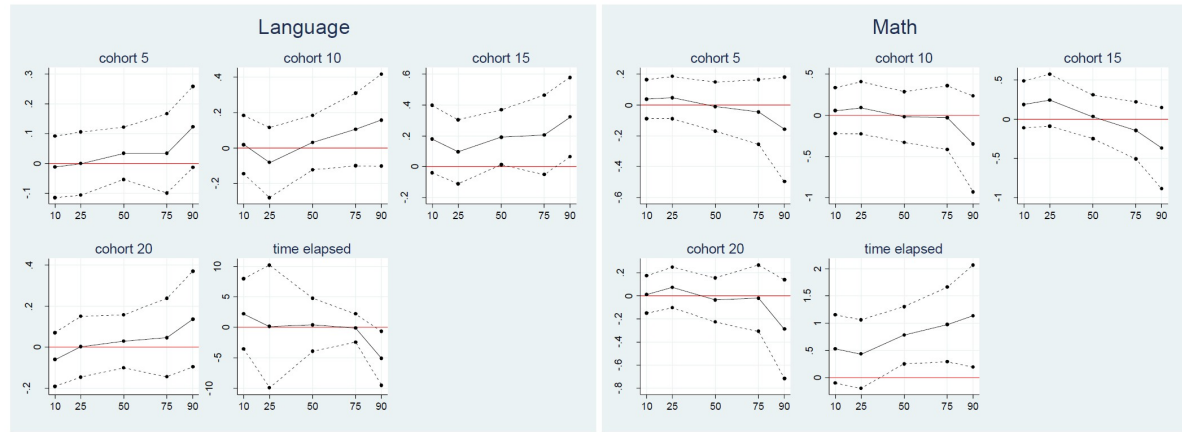

Source: SARESP, DRHU-SEE, School Census.

Figure 5. Effect of wages on proficiency ( $3^{\text {rd }}$ year of high school).

school, as of the $25^{\text {th }}$ percentile (for the teacher cohort that in 2007 had between five and nine years of service time - T5). This impact is of the order of 0.064 to 0.093 standard deviations of the grades. The positive correlation between the salary increase and language proficiency for $5^{\text {th }}$-year students, however, is only observed for this group of teachers. We also did not observe positive impacts of the wage increase on proficiency in mathematics, as a result of the estimation of the model (2).

When we control for possible heterogeneities among the different admission cohorts (model (1)), we are not able to affirm that the salary increase impacts language grades in the $5^{\text {th }}$ year, since the estimated coefficients are no longer statistically significant. However, in this specification, we found a positive correlation between the increase of the additional per quinquennium and the math scores, in the $10^{\text {th }}, 25^{\text {th }}$ and $90^{\text {th }}$ percentiles of grades. The estimated 
coefficients have a very high magnitude, of the order of 0.243 to 0.315 standard deviations of the note. In summary, the results are not robust to the different specifications, so we cannot conclude from the positive impact of the wage increase on proficiency in the $5^{\text {th }}$ year of elementary school.

The same can be said for the $9^{\text {th }}$ year of elementary school and the $3^{\text {rd }}$ year of high school. In Tables 5 and 6 , we see that there are few coefficients related to the impact of wage increase on proficiency that are statistically significant and even they have a level of significance at only $10 \%$. These results show that, in general, there is no correlation between the $5 \%$ salary increase coming from the quinquennial additional and the grades in language and mathematics, either in the estimation of model (1) or model (2). The exception is regression for math in the $3^{\text {rd }}$ year of high school, estimated from intracohort analysis, which considers the time elapsed since the teacher completed a five-year cycle of service time. In this specification, almost all coefficients are statistically significant and $5 \%$. The estimated points range from 0.528 to 1.135 standard deviations, suggesting salary impacts on proficiency too high to be credible.

In summary, our estimates do not point to robust results of the effects of increases in regular wages on proficiency, which is consistent with most studies in the literature on Economics of Education. The lack of effects of wages on learning may have two explanations. First, these estimates reflect a kind of income effect. Since the additional per quinquennium is known and anticipated by the teacher, a mechanism according to which this variation in teacher compensation would affect proficiency would be through her reallocation of time. According discussed in section 4 , it is reasonable to assume that teachers with lower wages engaged in other professional activities. Thus, in an economy with a credit restriction, the additional per quinquennium could stimulate the teacher to reallocate her time, reducing other professional activities and increasing her dedication to teaching activities in São Paulo educational system. However, we can argue that the value received by teachers monthly ( $\mathrm{R} \$ 106.27$, on average) is not sufficient to promote this reallocation of time. In the other hand, it can also be suggested that, since the receipt of quinquennium bonus is not tied to any measures of teacher performance or to additional requirements of their tasks or work routine, there is no incentive for the teacher to devote more time to improving quality of your class (such as preparing exercises, improving learning methods or participating more in school activities), even if it allows her to reduce the number of hours she work in other activities. Unfortunately, we do not have 
good information to reflect the allocation of teachers' time between different professional activities and even the tasks related to the teacher's dedication to school that permit us to speculate on these possibilities. ${ }^{6}$

\section{Final comments}

The remuneration of public school teachers in Brazil is pointed as an important policy for improving the quality of education. In addition, several educational systems have been adopting different remuneration policies for teachers, linked to the performance of their students in proficiency exams. In this article, we study the effects of salary increase of the teachers on the performance of the students in the São Paulo state public educational system, taking advantage of the existence of an exogenous wage variation rule given by the quinquennium rule.

Under this rule, every five years of service time, teachers receive an increase in the regular salary of $5 \%$. The date of admission of teachers is used to evaluate their eligibility for salary increases and the time of exposure of teachers who received additional wages, exploring the differences in the timing of contracting teachers throughout the year. As this gratification is known and therefore anticipated by the teacher, our estimates provide the impact of an income effect on proficiency, whose transmission mechanism could be given by the reallocation of the teacher's time, increasing her availability for beneficial activities for the students.

In order to control the impacts of other variables that may confuse the teachers' salary effect by also depending on the time of admission (for example, experience), in addition to other possible heterogeneities among teacher cohorts, we conduct identification strategies through differences-in-differences, exploring the variation between cohorts and variation over time. The estimates found, however, do not provide empirical evidence to conclude that the increase in regular wages can improve student learning. It is possible to argue that the magnitude of the salary increase given by the service time additional is not sufficient to promote the reallocation of the teacher's time. Or, it may be

\footnotetext{
${ }^{6}$ However, if this is a reasonable mechanism, we would expect that the impacts of increased regular wages on proficiency would be higher among teachers who have the greatest chance of reallocating their time between different professional activities, (12, 20, 30 hours) vis-à-vis those who have a full-time contract (40 hours). For this reason, we estimated the regressions of models (1) and (2) separately for four different samples of teachers, considering their work contract. The results are qualitatively the same.
} 
suggested that although this mechanism is possible, there is no incentive for the teacher to exert more effort, since receipt of the bonus is not linked to learning activities or performance.

\section{References}

Boyd, D., Lankford, H., Loeb, S., Rockoff, J., \& Wyckoff, J. (2007, September). The narrowing gap in New York City teacher qualifications and its implications for student achievement in high-poverty schools (Working Paper No. 10). Washington, DC: The Urban Institute - CALDER. Retrieved from https://eric.ed.gov/?id=ED498669

Cassandra M. Guarino, L., Santibañez, Daley, G. A., \& Brewer, D. J. (2004, May). $A$ review of research literature on teacher recruitment and retention (TR164-EDU). Santa Monica, CA. Retrieved from https://www.rand.org/ pubs/technical_reports/TR164.html

Chevaliar, A., Dolton, P., \& McIntosh, S. (2007). Recruiting and retaining teachers in the UK: An analysis of graduate occupational choice from the 1960s to the 1990s. Economica, 74(293), 69-96. http://dx.doi.org/ 10.1111/j.1468-0335.2006.00528.x

Darling-Hammond, L., \& Hudson, L. (1989, December). Pre-college science and mathematics teachers: Supply, demand, and quality (RAND Note N-2845-NSF). Santa Monica, CA. Retrieved from http://www.dtic.mil/ $\mathrm{dtic/tr/fulltext/u2/a258075.pdf}$

Dolton, P. J. (1990). The economics of UK teacher supply: The graduate's decision. The Economic Journal, 100(400), 91-104. http://dx.doi.org/ $10.2307 / 2234187$

Dolton, P. J., \& Makepeace, G. H. (1993). Female labor force participation and the choice of occupation: The supply of teachers. European Economic Review, 37(7), 1393-1411. http://dx.doi.org/10.1016/0014-2921(93) 90062-F

Han, Y.-K., \& Rossmiller, R. A. (2004). How does money affect teachers' career choices? Evidence from NLS-72. Journal of Education Finance, 30(1), 79-99. http://dx.doi.org/https://www.jstor.org/stable/40704221

Hanushek, E. A. (2003). The failure of input-based schooling policies. The Economic Journal, 113(485), F64-F98. http://dx.doi.org/10.1111/1468 $-0297.00099$

Hanushek, E. A., \& Raymond, M. E. (2005). Does school accountability lead to improved student performance? Journal of Policy Analysis and Management, 24(2), 297-327. http://dx.doi.org/10.1002/pam.20091

Hanushek, E. A., \& Rivkin, S. G. (2006). Teacher quality. In E. Hanushek \& F. Welch (Eds.), Handbook of the economics of education (Vol. 2, pp. 10511078). Elsevier. http://dx.doi.org/10.1016/S1574-0692(06)02018-6 
Johnson, S. M., Berg, J. H., \& Donaldson, M. L. (2005). Who stays in teaching and why: A review of the literature on teacher retention. Washington, DC: NRTA's Educator Support Network. Retrieved from https://projectngt.gse.harvard.edu/publications/who -stays-teaching-and-why-review-literature-teacher-retention

Leigh, A. (2012). Teacher pay and teacher aptitude. Economics of Education Review, 31(3), 41-53. http://dx.doi.org/10.1016/j.econedurev.2012.02 .001

Loeb, S., \& Page, M. E. (2000). Examining the link between teacher wages and student outcomes: The importance of alternative labor market opportunities and non-pecuniary variation. The Review of Economics and Statistics, 82(3), 393-408. http://dx.doi.org/10.1162/003465300558894

Manski, C. F. (1987). Academic ability, earnings, and the decision to become a teacher: Evidence from the National Longitudinal Study of the high school class of 1972. In D. A. Wise (Ed.), Public sector payrolls (pp. 291316). University of Chicago Press. Retrieved from http://www.nber.org/ chapters/c7157

Milanowski, A. (2008). Do teacher pay levels matter? (A New Series of Papers on Teacher Compensation from University of Wisconsin CPRE Group)

Podgursky, M. (2011). Teacher compensation and collective bargaining. In E. A. Hanushek, S. Machin, \& L. Woessmann (Eds.), Handbook of the economics of education (Vol. 3, pp. 279-313). Elsevier. http://dx.doi.org/ 10.1016/B978-0-444-53429-3.00005-3

Rumberger, R. W. (1987). The impact of salary differentials on teacher shortages and turnover: The case of mathematics and science teachers. Economics of Education Review, 6(4), 389-399. http://dx.doi.org/10.1016/0272 $-7757(87) 90022-7$

Shin, J., \& Moon, S. (2006). Fertility, relative wages, and labor market decisions: A case of female teachers (Vol. 25) (No. 6). http://dx.doi.org/10.1016/ j.econedurev.2005.06.004

Southwick, L., Jr, \& Gill, I. S. (1997). Unified salary schedule and student SAT scores: Adverse effects of adverse selection in the market for secondary school teachers. Economics of Education Review, 16(2), 143-153. http:// dx.doi.org/10.1016/S0272-7757(96)00055-6

Zibalza, A. (1979). The determinants of teacher supply. Review of Economic Studies, 46(1), 131-147. http://dx.doi.org/10.2307/2297177 